\title{
A NARRATIVA DE CLARICE LISPECTOR NO CORAÇÃO SELVAGEM DO BRASIL NO SÉCULO XX: ALGUNS ASPECTOS SOCIOPOLÍTICOS
}

\author{
Francisco Carlos Carvalho da Silva* \\ Geórgia Gardênia Brito Cavalcante Carvalho*
}

RESUMO: O objetivo principal do presente artigo consiste numa breve análise da literatura de Clarice Lispector (1920-1977), especificamente das crônicas "Mineirinho" (1962) e "Carta ao Ministro da Educação" (1968), seguidas da novela $A$ bora da estrela (1977) e dos contos "Felicidade clandestina" (1971) e "A bela e a fera ou a ferida grande demais" (1977). Tendo em vista que a obra literária da autora é ampla e diversa, escolhemos como temáticas a serem analisadas, a presença de alguns aspectos sociopolíticos observáveis na sua produção literária. Analisar a narrativa de Clarice Lispector pelo viés sociopolítico mostra-se relevante, uma vez que, na maioria das vezes, esses elementos são deixados de lado nas análises que são dedicadas à sua obra. Como base teórica, recorremos aos trabalhos de Candido (2000), Lucas (1970), Hobsbawm (1995), Bauman (2015) e Heller (2016) entre outros.

PALAVRAS-CHAVE: Clarice Lispector; Literatura brasileira; Narrativas; Política; Sociedade.

\section{Considerações iniciais}

A obra de Clarice Lispector (1920-1977) insere-se no contexto da literatura produzida no século XX, uma era de extremos, como bem classificou o historiador Eric Hobsbawm (1917-2012). A literatura produzida por Clarice Lispector a partir de Perto do Coração Selvagem (1943), seu trabalho de estreia, a coloca no centro da literatura que vinha sendo produzida no Brasil. Como toda grande obra, a literatura da autora de Água Viva (1973) discute temáticas que são caras e recorrentes na constituição da literatura universal, com tudo aquilo que a comanda, a saber, a sociedade, o cotidiano e, obviamente, a condição humana. Elementos como estes não são específicos da literatura moderna ou contemporânea, uma vez que já estão presentes na raiz das obras fundantes da literatura universal, como aquela produzida por Homero (928 a. C- 898 a. C), na Odisseia (século VIII a. C) e na Ilíada (século VIII a. C), por exemplo.

Assim sendo, a literatura de Clarice Lispector se sente acompanhada das outras grandes obras produzidas no âmbito do século XX, entre as quais poderíamos citar o Ulisses (1922), de James Joyce (1882-1941), obra determinante para a renovação das formas de narrar a partir de então. O amor, a vida e a morte como elementos das narrativas literárias modernas

\footnotetext{
* Doutor em Linguística Aplicada pela Universidade Estadual do Ceará (Uece). Professor da Faculdade de Educação, Ciências e Letras do Sertão Central (FECLESC/Uece).

** Doutoranda em Literatura Comparada pela Universidade Federal do Ceará (UFC). Mestre em Estudos da Tradução pela UFC.
} 
são, por sua vez, constituintes daquilo que se compreende como "condição humana", cujas características principais são os fatores preponderantes da existência.

Observando-se por este ângulo, uma compreensão da existência humana, no contexto social, exige a observância de elementos filosóficos, sócio-históricos, sociopolíticos e antropológicos entre outros, que se dão na obra de arte como um todo, mas na obra literária em específico, uma vez que não existe obra literária que não comporte, de uma forma ou outra, estes aspectos; tendo em vista a arte estar sempre em consonância com um tempo e um espaço históricos, como pode ser notado em obras díspares no espaço e no tempo, como Em busca do tempo perdido (1913), de Marcel Proust (1871-1922) e Quarto de despejo: diário de uma favelada (1960), de Carolina Maria de Jesus (1914-1977), por exemplo.

Assim sendo, ao longo deste artigo, discorreremos sobre a narrativa de Clarice Lispector, analisando a presença de alguns aspectos sociais e políticos presentes em sua obra. Para tanto, organizamos o trabalho em quatro tópicos, a saber, no primeiro tópico, denominado de "Clarice Lispector: uma narrativa no coração selvagem do Brasil dos anos 60 e 70", discorremos sobre o lugar da obra da autora no contexto histórico do século XX, enfatizando sua produção literária das décadas de 60 e 70, tendo como panorama a ditadura civil-militar implantada no Brasil com o golpe de 1964. No segundo tópico, intitulado de "Crônicas de uma realidade anunciada", tomamos como objeto de análise as crônicas "Mineirinho", de 1962 e "Carta ao Ministro da Educação", de 1968, observando como determinados aspectos sociais e políticos se fazem presentes nestes dois textos, mostrando-se como anunciadores de uma realidade nacional que ainda estava por vir. O terceiro tópico, por sua vez, é dedicado a uma apresentação de algumas dicotomias sociopolíticas observáveis na tessitura da novela A hora da estrela, de 1977. Por fim, no quarto tópico, tomamos os contos "Felicidade clandestina" (1971) e "A bela e a fera ou a ferida grande demais" (1977), como exemplos que reforçam a presença do social e do político como elementos recorrentes e indissociáveis dos demais aspectos que constituem a narrativa de Clarice Lispector. A este tópico, demos o nome de "Felicidades clandestinas e feridas grandes demais".

\section{Clarice Lispector: uma narrativa no coração selvagem do Brasil dos anos 60 e 70}

A obra de Clarice Lispector é toda ela gestada no contexto sócio-histórico do século XX, uma vez que é neste período que a referida autora nasce (1920), vive, produz e morre (1977). Trata-se de um dos séculos mais conturbados da história da humanidade, cujas duas Grandes Guerras, por exemplo, causaram danos irreversíveis em todos os âmbitos da sociedade, fazendo do mundo, nas palavras poéticas de T.S. Eliot (1888-1965), uma terra 
devastada. No caso da Europa, há um crescimento da população, devido ao grande fluxo de emigrantes, o que nos lembra que Clarice Lispector e sua família, fugindo da perseguição aos judeus, após a Revolução Bolchevique de 1917, emigra da Rússia para a América do Sul, chegando ao Brasil no ano de 1922.

Observando-se as metamorfoses sócio-históricas causadas pelo belicismo do período, pode-se perceber o quanto era selvagem o coração do século XX. E é neste contexto sociopolítico que surge a obra literária de Clarice Lispector, na qual pode-se identificar referências às fraturas físicas e espirituais em um ser humano quebrado, em meio a uma sociedade em desconstrução. Sobre a sociedade, sua desconstrução e percalços desta era de extremos, convém observarmos aquilo que afirma Eric Hobsbawm (1995):

Para a sociedade, as décadas que vão da eclosão da Primeira Guerra Mundial aos resultados da Segunda foram uma Era de Catástrofe. Durante quarenta anos, ela foi de calamidade em calamidade. Houve ocasiões em que mesmo conservadores inteligentes não apostariam em sua sobrevivência. Ela foi abalada por duas guerras mundiais, seguidas por duas ondas de rebelião e revolução globais que levaram ao poder um sistema que se dizia a alternativa historicamente predestinada para a sociedade capitalista e burguesa e que foi adotado, primeiro, em um sexto da superfície da Terra, e, após a Segunda Guerra Mundial, por um terço da população do globo. (HOBSBAWM, 1995, p. 16)

É em meio à esta Era de Catástrofe que Clarice Lispector se inicia, oficialmente, na literatura. No ano de 1943, a autora publica o romance Perto do coração selvagem. No ano de 1946, lança O Lustre. Registre-se que a Segunda Guerra Mundial ocorreu de 1939 a 1945, envolvendo não apenas as grandes potências mundiais, mas arrastando para o conflito países periféricos como o Brasil, por exemplo. É então neste contexto belicista que são produzidos seus primeiros trabalhos, quando ainda contava menos de trinta anos de idade. 1949, por sua vez, é o ano de publicação do romance $A$ cidade sitiada. A opção pela lexia "sitiada" mostrase bastante oportuna e em consonância com o zeitgeist, mostrando a romancista como uma observadora atenta ao mundo.

Note-se que um ano antes da publicação de Cidade sitiada (1949), exatamente em 1948, Albert Camus (1913-1960) publicara a peça Estado de sitio, a qual tinha como fio condutor o medo, considerado pelo autor francês como o grande mal do século XX. Assim sendo, a peça de Camus constituía-se como uma alegoria dos regimes totalitários impostos ao mundo na década de 40. Politicamente falando, o Brasil também vivia em estado de exceção, em consequência do golpe de Estado liderado por Getúlio Vargas em 1937, sucedido pelo governo militar de Eurico Gaspar Dutra, de 1946 a 1951, quando tem-se a volta de Vargas ao poder. Logo, o sentimento de medo externado por Camus, também pairava por sobre as vidas sitiadas e as liberdades vigiadas de um Brasil em desencanto. 
Embora tenha começado a publicar na década de 40, o ápice da produção da autora de Laços de família (1960) dá-se nos anos 60. Decisivos para a cultura mundial, os anos 60 foram palco de eventos culturais e movimentos políticos sociais que marcaram de maneira indelével a vida humana. Se na Europa, especificamente na França, ocorriam os movimentos de libertação sexual, cultural e política; nos Estados Unidos tinha-se o acirramento da luta pelos direitos civis, bem como o desenrolar dos movimentos de contracultura, responsáveis por trazer ao palco do mundo a literatura da Geração Beat e a ascensão de nomes como Bob Dylan, por exemplo.

No Brasil, no entanto, estava em curso a ditadura civil-militar surgida com o golpe de 1964, considerada uma das mais sangrentas da América Latina, e que só terminaria no ano de 1985. Durante este período de exceção, militantes de partidos políticos, professores, políticos, artistas e escritores foram perseguidos e banidos do convívio social. Muitos foram presos, torturados, exilados, desaparecidos e assassinados. O clima era de medo, perseguição e terror. Alguns artistas, no entanto, conseguiam driblar a censura e continuar produzindo. Enquanto muitos optaram pela "neutralidade", outros se assumiram como agentes da repressão, tomando para si a função de delatores de amigos, vizinhos e colegas de trabalho. Naquela época, mas já no início da década de 70, após a promulgação do Ato Institucional número 5, o AI-5, surgiu aquilo que ficou conhecido como patrulhamento ideológico.

Sobre essa questão, Araújo, no livro Eu não sou cachorro, não (2015), no qual discorre sobre música popular cafona no período da ditatura civil-militar brasileira, afirma que:

Naquela época Henfil publicava semanalmente no Pasquim uma coluna conhecida
como "cemitério dos mortos-vivos", no qual ele fazia o "enterro" daquelas pes-
soas que considerava simpatizantes do regime militar ou omissas politicamente
[...] nas lápides do "cemitério" de Henfil apareciam os nomes de personalidades
como Roberto Carlos, Pelé, Nelson Rodrigues, Gilberto Freyre, Raquel de Quei-
roz, Zagalo, Bibi Ferreira, Clarice Lispector, Marília Pêra e também Elis Regina.
(ARAÚJO, 2015, p.287 - grifo nosso)

Ao contrário do que pensava Henfil, a partir da narrativa de Clarice Lispector, é possível inferir que a autora não era politicamente alienada nem defendia a ditadura. Ao contrário, Clarice Lispector, como ela mesma chegou a afirmar, era “engajada”. Sobre isso, observemos uma fala da autora, transcrita por Chiappinni (2004) no artigo "Clarice e a crítica: por uma perspectiva integradora”. Diz ela: “... na verdade, sinto-me engajada. Tudo que escrevo está ligado, pelo menos dentro de mim, à realidade em que vivemos". Não se tem notícia também de atitudes preconceituosas externadas ou sofridas pela autora de $A$ bora da estrela (1977). É claro que a posição de Clarice Lispector na sociedade brasileira a "blindava" de 
ataques e agressões. O mesmo não acontecia com autores e autoras menos privilegiados, como Carolina Maria de Jesus, por exemplo.

Uma constatação do que afirmamos se dá quando as duas escritoras se encontraram. $\mathrm{Na}$ ocasião, Clarice Lispector disse para Carolina Maria de Jesus que sua literatura era verdadeira, ao tempo que Carolina Maria de Jesus disse para Lispector que sua literatura era elegante. Não se pode desconsiderar que a aproximação de Clarice Lispector com Carolina Maria de Jesus consistia também num posicionamento político, ao contrário daquilo que, dez anos após aquele encontro, afirmaria Henfil no Pasquim. Como dito, por sua posição social, Clarice Lispector estava "blindada" de preconceitos e ataques. Falamos das décadas de 60 e 70, quando ainda se normalizavam os mais doentios preconceitos. Lamentável mesmo é observar a recorrência de certos preconceitos em dias atuais, algo que certamente não condiz com Clarice Lispector, tendo em vista as temáticas sociopolíticas que abordou em sua obra. Um exemplo do que afirmamos é o ataque racista de Benjamim Moser, autor de Clarice, uma biografia (2009) à imagem de Carolina Maria de Jesus. Ao comentar uma fotografia na qual estão Carolina Maria de Jesus e Clarice Lispector, o biógrafo diz:

\footnotetext{
[...] Numa foto, ela aparece em pé, ao lado de Carolina Maria de Jesus, negra que escreveu um angustiante livro de memórias da pobreza brasileira, Quarto de despejo, uma das revelações literárias de 1960. Ao lado da proverbialmente linda Clarice, com a roupa sob medida e os grandes óculos escuros que a faziam parecer uma estrela de cinema, Carolina parece tensa e fora do lugar, como se alguém tivesse arrastado a empregada doméstica de Clarice para dentro do quadro [...] (MOSER, 2009, p.22)
}

Clarice Lispector, uma imigrante ucraniana, chegada ao Brasil no ano de 1922, e cujas origens não se diferenciam muito das de Carolina Maria de Jesus, não ficou alheia aos elementos sociais e políticos que constituíam a sociedade na qual estava inserida; elementos estes que podem ser notados em suas narrativas, sejam elas romances, novela, contos ou crônicas, desconstruindo a impressão falseada e reproduzida ad nauseam de que a autora de A bela e a fera (1999) teria se limitado a produzir uma literatura meramente intimista, apartada da realidade e do cotidiano. Ao contrário do que alguns poderiam pensar, a narrativa clariciana é repleta de aspectos sociais e políticos, que a tomam de uma abrangência temática que vai muito além de uma narrativa puramente intimista. Deixemos claro, no entanto, que não há nada que deponha contra narrativas intimistas, muito menos a narrativa intimista de Clarice Lispector. Alguns casos os aspectos sociopolíticos presentes na narrativa da autora surgem de forma mais evidente e clara, em outros, de forma mais discreta, mas não menos contundente. 
No que concerne à presença de aspectos sociopolíticos como constituintes de uma narrativa, observa-se que podem se dar de forma explícita ou não, dependendo da maestria e dos objetivos de quem escreve. A falta de habilidade do autor/da autora ao recorrer a aspectos sociopolíticos na construção de suas narrativas, assim como a falta de objetividade quanto aos seus usos podem transformar aquilo que pretendia ser uma obra literária num simples panfleto político, destituído de quaisquer qualidades literárias. No caso da narrativa clariciana, isso não ocorre, tendo em vista que as estruturas narrativas são elaboradas de forma que os posicionamentos sociopolíticos presentes na narração não dominem o texto, mas que se façam presentes e indispensáveis.

\section{Crônicas de uma realidade anunciada}

A agudização da violência no Brasil contemporâneo tem raízes profundas que remetem ao período colonial, passando pelo Brasil Império, resultando na realidade que se vê, ou seja, trata-se de um fenômeno histórico, para o qual nunca se pensou uma solução, a não ser paliativos arranjos sociais. Assim sendo, a ausência de políticas públicas sérias de combate à violência contribuiu para o aumento da violência urbana no país, tendo em vista o imenso abismo da desigualdade social que se instalou na sociedade brasileira ao longo dos tempos. Neste sentido, ao se mostrar incompetente e alheio no que diz respeito à proposição de políticas públicas inclusivas, o Estado brasileiro acostumou-se a normalizar a situação, excluindo e criminalizando, por exemplo, os mais pobres, contribuindo assim para o aumento da população carcerária e a estigmatização do povo negro. Neste contexto, destaca-se também a violência policial, que tem sido recorrente, tendo sempre como vítimas preferenciais os pobres, pretos e marginalizados.

Atenta às questões nacionais e preocupada com o aumento da violência urbana, já no ano de 1962, Clarice Lispector escreve uma crônica chamada "Um grama de radium - Mineirinho", que lhe havia sido solicitada pelo conselho editorial da revista Senhor, para a qual Clarice escrevia desde 1958. A narrativa é sobre a morte, no Rio de Janeiro, de um perigoso bandido chamado José Miranda Rosa, que por ter nascido em Minas Gerais, atendia pelo apelido de Mineirinho. Mineirinho tornou-se figura famosa naqueles anos por suas insistentes e perigosas infrações. Diz-se que Mineirinho assaltava à luz do dia e que não temia a polícia. Havia registro de que Mineirinho já fugira algumas vezes da cadeia e tantas outras do Manicômio Judiciário. Somadas todas suas condenações, diz-se que Mineirinho tinha pelo menos um século de prisão a cumprir. Contudo, a população tinha em Mineirinho, um herói, uma espécie de Robin Hood, o que desagradava ainda mais os órgão de segurança pública. 
Assim, com o objetivo de recapturar o fugitivo Mineirinho, a Polícia Militar do Rio de Janeiro montou uma força-tarefa com mais de trezentos homens. O resultado da operação é que, encurralado pela polícia, Mineirinho foi morto com nada menos que treze tiros.

Ao abordar esse assunto em sua crônica, Clarice Lispector se mostra indignada com banalização da violência policial e a ausência de justiça no país. Naquela época, nem passava pela cabeça da autora que uma pessoa, em pleno século XXI, pudesse ser morta por oitenta, noventa ou até cem tiros, por forças militares pagas para servir e proteger, sem ninguém ser responsabilizado, muito menos condenado por isso. A crônica "Um grama de radium - Mineirinho", seria publicada pela primeira vez em livro, no ano de 1978, em Para não esquecer, com o nome "Mineirinho". Essa mudança no nome da crônica, excluindo-se a expressão "um grama de radium”, acaba por esvaziar sua significação.

Sabendo-se que o rádio (radium, do latim) é o elemento atômico 88, altamente radioativo, e que apenas um grama seu já poderia causar um acidente radioativo de grandes proporções, ao intitular sua crônica de "Um grama de radium - Mineirinho", a cronista não está classificando a personagem Mineirinho como algo "radioativo". O que é "radioativo" neste contexto é o avanço da violência urbana observada pela autora, especificamente a violência policial, cujo crescimento exponencial já se mostrava preocupante nos primeiros anos da década de 60. Naquele período, a violência urbana era apenas "um grama", demonstrado na ação da polícia deflagrada contra Mineirinho, mas que já se mostrava como um indicativo da "radioatividade" que viria a tomar conta do país futuramente. Assim sendo, ao se reduzir o título da crônica para apenas "Mineirinho" tem-se uma perda significativa na carga semântica que a expressão "Um grama de radium" carrega, deslocando o foco da radioatividade da violência urbana, denúncia principal da crônica, para a figura secundária do Mineirinho, a vítima.

Sobre como se sente acerca do assassinato de Mineirinho, a narradora diz:

\footnotetext{
Esta é a lei. Mas há alguma coisa que, se me faz ouvir o primeiro e o segundo tiro com um alívio de segurança, no terceiro me deixa alerta, no quarto desassossegada, o quinto e o sexto me cobrem de vergonha, o sétimo e o oitavo eu ouço com o coração batendo de horror, no nono e no décimo minha boca está trêmula, no décimo primeiro digo em espanto o nome de Deus, no décimo segundo chamo meu irmão. O décimo terceiro tiro me assassina — porque eu sou o outro. Porque eu quero ser o outro. (LISPECTOR, 1999b, p. 123-124)
}

Na rara entrevista que concedeu à TV Cultura no ano de 1977, ao falar sobre o caso Mineirinho, Lispector declarou que qualquer que fosse o crime dele, uma bala bastava, o resto disse ela, era vontade de matar. Era prepotência. Note-se aqui, que a autora já criticava os excessos da violência policial na década de 60, denunciando o modus operandi do Estado ao 
eliminar os indesejáveis ao sistema, geralmente bandidos pobres, descumprindo, para tanto, as leis, e ignorando a justiça, em flagrante desrespeito ao Estado de Direito. Observe-se que, desde a primeira publicação da crônica de Clarice Lispector, os casos de violência policial no Brasil só aumentaram, fazendo com que o país tenha hoje uma das polícias que mais letais do mundo, o que já se constitui como um problema de saúde pública, conforme aquilo que determina a Organização Mundial de Saúde.

Ao abordar temas ásperos nas crônicas publicadas em grandes jornais, Lispector tinha a consciência do alcance que teriam, uma vez que os jornais ainda eram as principais fontes de informação da época. Deste modo, Lispector sabia que ao escrever para jornais como o Jornal do Brasil, estava falando para o país. Neste sentido, a crônica, por seu caráter híbrido de literatura e jornalismo, era o gênero perfeito para a abordagem de determinados temas. Sobre a crônica e seu caráter híbrido, Jorge de Sá (1985) observa:

\begin{abstract}
Sendo a crônica uma soma de jornalismo e literatura (daí a imagem do narradorrepórter, dirige-se a uma classe que tem preferência pelo jornal em que ela é publicada (só depois é que irá ou não integrar uma coletânea, geralmente organizada pelo próprio cronista), o que significa uma espécie de censura ou, pelo menos, de limitação: a ideologia do veículo corresponde ao interesse dos seus consumidores, direcionados pelos próprios proprietários do periódico e/ou pelos editores-chefes de redação. Ocorre ainda o limite de espaço, uma vez que a página comporta várias matérias, o que impõe a cada uma delas um número restrito de laudas, obrigando o redator a explorar da maneira mais econômica possível o pequeno espaço de que dispõe. É dessa economia que nasce sua riqueza estrutural. (SÁ 1985, p. 78)
\end{abstract}

Os questionamentos sociopolíticos levantados por Lispector na crônica "Mineirinho" ganharão tons mais fortes, seis anos depois, na crônica "Carta ao Ministro da Educação, publicada no Jornal do Brasil, no dia 17 de fevereiro de 1968, quando a cronista se manifesta sobre a decisão do MEC, que divulgara um edital anunciando que os vestibulares passariam a ser classificatórios, o que excluiria do processo muitos jovens, principalmente os mais pobres. Ressalte-se que a referida crônica é publicada 1968, o ano mais violento da ditadura, com inúmeros desaparecimentos, torturas e assassinatos promovidos pelos órgãos de repressão do Estado. Reiteramos que é neste ano, no dia 13 de dezembro, que é promulgado o Ato Institucional número 5, conhecido como o AI-5, que deu plenos poderes ao Estado, para censurar, prender, torturar e matar. Logo, qualquer ação que desagradasse ao governo de exceção, por mínima que fosse, poderia acarretar em violentas represálias.

A crônica "Carta ao Ministro da Educação" diz o seguinte:

Em primeiro lugar queríamos saber se as verbas destinadas para a educação são distribuídas pelo senhor. Se não, essa carta deveria se dirigir ao presidente da República. A este não me dirijo por uma espécie de pudor, enquanto sinto-me com mais direito de falar com o ministro da Educação por já ter sido estudante. $\mathrm{O}$ 
senhor há de estranhar que uma simples escritora escreva sobre um assunto tão complexo como o de verbas para educação - o que no caso significa abrir vaga para os excedentes. Mão o problema é tão grave e por vezes patético que mesmo a mim, não tendo ainda filhos em idade universitária, me toca. [...] Senhor ministro ou Presidente da República, impedir que jovens entrem em universidade é crime. Perdoe a violência da palavra. Mas é a palavra certa. [...] Falei com uma jovem que foi excedente, perguntei-lhe como se sentira. Respondeu que se sentira desorientada e vazia, enquanto ao seu lado rapazes e moças, ao se saberem excedentes, ali mesmo começaram a chorar. E nem poderiam sair à rua para uma passeata de protesto porque sabem que a polícia poderia espancá-los [...]. Que estas páginas simbolizem uma passeata de protesto de rapazes e moças. (LISPECTOR. 1992, p. 73-74)

A crônica "Carta ao Ministro da Educação" está publicada no livro $A$ descoberta do mundo (1992), da editora Francisco Alves. No entanto, ao se comparar com a publicação da mesma crônica no livro Todas as crônicas (2018), da editora Rocco, observa-se que um trecho da crônica foi suprimido na edição da Francisco Alves. Para efeito de comprovação do que dizemos, o trecho suprimido é:

[...] Não estou de modo algum entrando em seara alheia. Esta seara é de todos nós. E estou falando em nome de tantos que, simbolicamente, é como se o senhor chegasse à janela de seu gabinete de trabalho e visse embaixo uma multidão de rapazes e moças esperando seu veredicto [...]. (LISPECTOR, 2018, p. 77-78)

Ao afirmar que os jovens não poderiam nem ao menos sair às ruas para protestar contra a decisão do Ministério da Educação, pois poderiam ser espancados pela polícia, a cronista denuncia, como fizera em "Mineirinho", a violência policial como recorrente no país, que não dispensava nem mesmo os jovens. Se em "Mineirinho" a violência policial era mais localizada, em "Carta ao Ministro da Educação” percebe-se que já é de caráter nacional. Notese que, mesmo sob a ditadura, a cronista não baixa a guarda, ao contrário, posiciona-se como cidadã e exige respostas das autoridades constituídas.

As primeiras linhas são comprobatórias do que afirmamos, quando a cronista exige uma resposta a respeito das verbas destinadas à educação. Cobrar ou exigir de uma autoridade o que quer que fosse em plena ditadura era um ato, ao mesmo tempo, corajoso e arriscado. A cronista, no entanto, não recua, seguindo cada vez mais incisiva no seu posicionamento perante o absurdo da situação, quando diz: "Senhor ministro ou Presidente da República, impedir que jovens entrem em universidade é crime. Perdoe a violência da palavra. Mas é a palavra certa" (LISPECTOR, 1992, pp. 73-74). Assim, de forma direta, a cronista chama o Estado, na figura do Ministro da Educação, de criminoso. E conclui, dizendo esperar que aquilo que está ali escrito se materialize em uma passeata de protesto. Logo, além de classificar a ditadura de criminosa, a cronista ainda convoca os jovens para uma passeata, o que ia contra as determinações do regime de então. 
No trecho constante da publicação no Jornal do Brasil, mas excluído da edição em livro, a cronista deixa claro que discutir assuntos de educação não se constitui como uma questão individual, mas coletiva, uma vez que se trata de tema de interesse da nação. Ao assinar a referida crônica e dedicar a ela espaço em um grande veículo de comunicação, Lispector chama para si uma enorme responsabilidade, se expondo em tempos de feroz repressão militar. E embora coloque-se na linha de frente do confronto, não fala por si, mas pelo coletivo, pela sociedade brasileira, especificamente, pelos jovens. Destarte, não há como conceber qualquer forma de alienação em uma autora que se posiciona politicamente nestes moldes em relação a realidade sociopolítica estabelecida.

Sobre a relação do escritor com a realidade, a própria Lispector chegou a afirmar que:

O escritor não é um ser passivo que se limita a recolher dados da realidade, mas deve estar no mundo como presença ativa, em construção com o que o cerca. $\mathrm{Na}$ atividade de escrever o homem deve exercer a ação por desnudamento, revelar o mundo, o homem aos outros homens. E ao fazê-lo deverá escolher dizê-lo de um modo determinado, pessoal. Ele tem ou não a consciência de seu papel de "revelador" das coisas, o meio através do qual elas se manifestam e adquirem significado. [...] A literatura deve ter objetivos profundos e universalistas: deve fazer refletir e questionar sobre um sentido para a vida e, principalmente, deve interrogar sobre o destino do homem na vida. [...] Penso que o escritor deve dirigir-se à liberdade de seus leitores, integrados ou não na mesma situação histórica e para quem as realidades descritas sejam ou não alheias. E, ao fazê-lo, o escritor deve mobilizá-los a uma identificação, questionamento ou possível resposta. (LISPECTOR apud BORELLI, 1981, pp. 72-73)

Deste modo, percebe-se que seus posicionamentos políticos se dão, primeiramente pelas linhas constituintes de suas narrativas e, na sequência, de forma presencial em eventos em defesa da democracia, como lançamentos de livros e passeatas. Como dito, a crônica "Carta ao Ministro da Educação" foi publicada no Jornal do Brasil no dia 17 de fevereiro de 1968. No dia 26 de junho do mesmo ano ocorreu a passeata dos cem mil, a maior manifestação da sociedade brasileira contra a ditadura, que contou com a participação ativa de Clarice Lispector.

\section{A hora da estrela: dicotomias sociopolíticas}

No dia 1 de fevereiro de 1977, ano de sua morte, Clarice Lispector concedeu, como dissemos anteriormente, uma rara entrevista ao jornalista Júlio Lerner (1939-2007), na TV Cultura. Na ocasião, Lispector fala que havia concluído uma novela que tratava da história de uma moça que comia cachorro-quente. A história, disse ela, era de uma inocência pisada, de uma miséria anônima. O cenário da novela era o Rio de Janeiro. O personagem, no entanto, era nordestino, de Alagoas, concluía a autora. Lispector estava falando da novela $A$ hora da estrela, publicada no mesmo ano de 1977 e que, no momento da entrevista, não tinha 
esse nome. $\mathrm{Na}$ verdade, ainda não tinha nem título. Ao ser perguntada sobre o título da novela ela diz que tem treze nomes, treze títulos. Entre eles, um era "o direito ao grito". Mesmo não tendo ainda se decidido pelo título que daria à novela, a autora havia considerado "o direito ao grito" como uma das possibilidades de nomeação. Observe-se que a expressão "o direito ao grito" é prenhe de significação tanto social quanto política, não apenas por defender o direito a ter direito, mas a ter o direito de gritar, dando voz aos personagens subalternizados da narrativa, especialmente, as personagens femininas. Na ocasião, no entanto, ela não revela o nome do personagem, afirmando ser segredo.

Hoje sabemos que Clarice falava de $A$ bora da estrela, novela está repleta de aspectos sociopolíticos. O próprio título $A$ bora da estrela já remete, de certa forma, àqueles programas transmitidos pela televisão brasileira na década de setenta, que eram muitas vezes, a oportunidade para uma pessoa simples e anônima tornar-se uma "estrela" e, finalmente, sair da miséria. Assim, sabemos que a narrativa da novela, obviamente, não se resume a uma moça que come cachorro-quente. Muito mais do que isso, a narrativa de $A$ hora da estrela é exatamente sobre uma inocência pisada, de uma miséria anônima, que sabemos não ser tão anônima assim, uma vez que está na história do povo brasileiro, como realidade vivida, desde muito tempo.

Note-se que ao usar a expressão “moça que come cachorro-quente”, Lispector já mostra uma oposição entre culturas. De um lado tem-se a mulher nordestina, como representação do povo brasileiro. Do outro, tem-se cachorro-quente como representação da cultura norte-americana. Essa dicotomia mostra-se de forma mais efetiva na relação nordeste/sudeste, quando a narrativa aponta para o êxodo de nordestinos, que migram para as cidades grandes, geralmente Rio de Janeiro e São Paulo, em busca de trabalho e, consequentemente, melhorias de vida, o que acontecia para poucos. A maneira como Clarice Lispector estrutura a narrativa, indica que a autora de Felicidade Clandestina (1998) estava atenta aos fluxos migratórios que ocorriam no país, denunciando o abismo social existente no Brasil.

É possível afirmar que na referida novela, há uma forte crítica social, perpassada por elementos de ironia, como se pode perceber, por exemplo, nos nomes da personagem principal, Macabéa e seu namorado Olímpico de Jesus, postos como representações do povo brasileiro, abandonado à própria sorte, carente de instrução formal e sem consciência política, o que o torna joguete nas mãos dos políticos profissionais ou de ocasião. Para passar o tempo, a personagem Macabéa ouvia rádio. Para tanto, pedia emprestado o rádio de uma das mulheres, as três Marias, com quem dividia o quarto de pensão. E aqui tem-se uma aproximação das "marias" e "macabéas", de Lispector, com os "severinos", de João Cabral de Melo 
Neto (1920-1999), cujo poema Morte e Vida Severina fora publicado pela primeira vez no ano de 1955.

A denúncia da desigualdade social no Brasil, observada no poema cabralino, perpassa todo o texto clariciano, alcançando seu ápice quando Macabéa é atropelada por um Mercedes, já ao final da narrativa. Observe-se, mais uma vez as dicotomias. De um lado, Macabéa, como representação do povo brasileiro. Do outro, o Mercedes, como objeto representativo da ostentação de uma elite financeira que, somente em situações como a apresentada na obra ocupam o mesmo tempo e espaço físico social do subalterno. Publicada durante a ditadura civil-militar brasileira, $A$ hora da estrela é uma obra questionadora da sociedade excludente, assim como do sistema político em curso no país naquele período.

Assim sendo, ao discorrermos sobre alguns aspectos sociopolíticos na narrativa de Clarice Lispector, inevitavelmente, traz-se à discussão as relações de influência que o meio opera sobre a obra de arte, assim como a influência da obra de arte sobre o meio. Somente assim, conforme Antonio Candido, é que "poderemos chegar mais perto de uma interpretação dialética, superando o caráter mecanicista [...]" (CANDIDO, 2000, p. 18). Diante do que afirma Candido, pode-se deduzir, tradicionalmente falando, que há uma interdependência entre obra de arte e meio social. No entanto, é necessário observar, no entanto, que há uma quantidade grande e diversa de fatores sócio-históricos, políticos e culturais que agem na maneira como esta relação se desenvolve.

Acerca desta questão, Candido afirma que:

Para o sociólogo moderno, ambas as tendências tiveram a virtude de mostrar que a arte é social nos dois sentidos: depende da ação de fatores do meio, que se exprimem na obra em graus diversos de sublimação; e produz sobre os indivíduos um efeito prático, modificando a sua conduta e concepção do mundo, ou reforçando neles o sentimento dos valores sociais. Isto decorre da própria natureza da obra e independe do grau de consciência que possam ter a respeito os artistas e os receptores da arte. (CANDIDO, 2000, p.19)

Compreende-se, assim, que a literatura de Clarice Lispector se mostra em conexão com o meio no qual se insere, não apenas em relação à realidade social e política do período em que foi produzida, especificamente as décadas de 60 e 70, mas que se mantém cada vez mais atual, sendo capaz de influenciar, enquanto exemplo de obra literária, a sociedade contemporânea.

\section{Felicidades clandestinas e feridas grandes demais}

O panorama nacional no qual se insere a principal parte da produção literária de Clarice Lispector é todo ele de exceção, uma vez que o golpe civil-militar de 1964, como já aludimos, instalou uma ditadura que durou por vinte e um anos, terminando somente no ano de 1985. 
É neste contexto histórico, que Clarice Lispector produzirá, praticamente, toda sua obra. A crítica social e política presente na sua obra, especificamente em suas crônicas e novela, não para por aí, mas também se mostra em outros de seus textos, como nos contos, por exemplo. Assim sendo, dando continuidade àquilo que estamos discutindo, reforçamos, a partir de algumas considerações a seguir, a presença do social e do político na literatura da autora. Para tanto, tomamos dois de seus mais conhecidos contos, a saber, "Felicidade clandestina", de 1971 e "A bela e a fera ou a ferida grande demais", de 1977.

O período histórico no qual autora e obra se inserem, era de extrema hostilidade a todos aqueles que se opunham ao regime. Clarice Lispector, que se recusou a seguir a "escravidão dos gêneros", criando o "estilo Clarice" de escrever, demonstra também ter se negado à submissão de qualquer outra forma de escravidão, inclusive àquelas persecutórias. Um exemplo do que afirmamos é o lançamento do seu livro de contos Felicidade clandestina, publicado em plena ditadura, no ano de 1971, tendo uma segunda edição em 1975. O livro, composto de 25 contos, também chama a atenção pelo título provocativo e insubmisso, que se mostra como uma forma de resistência e desafio ao sistema ditatorial que tomara o país de assalto. Estar em estado de felicidade poderia ser compreendido como um ataque ao governo autoritário em curso no país, restando aos "felizes" à clandestinidade. Logo, o título "Felicidade clandestina", implicava numa tomada corajosa de posicionamento da autora, funcionando como um indicativo de que, tendo em vista o estado das coisas, só seria possível ser feliz na clandestinidade.

Dos vinte e cinco contos de Felicidade clandestina (1971), o primeiro tem o mesmo nome do título. Neste conto, a desigualdade social é apresentada a partir da oposição entre duas meninas, uma rica e uma pobre. Aqui, como já fizera em $A$ bora da estrela (1977), Lispector recorre ao uso da dicotomia, tomando a imagem das duas meninas como uma representação das classes sociais do país.

A narrativa apresenta, de um lado, a angústia e a frustração de uma garota pobre, que gosta de livros, mas que não tem como comprá-los. Do outro lado, tem-se a menina, que é filha de um dono de livraria, mas que não demonstra interesse pela leitura, não se dispondo a emprestar seus livros, especificamente o livro Reinações de Narizinho (1931), de Monteiro Lobato (1882-1948), aos amigos, representados pela menina pobre.

Aparentemente, a narrativa de Felicidade clandestina (1971) limita-se à relação de oposição entre as duas meninas, mas só aparentemente, pois o conto vai além, podendo ser compreendido como uma forma de questionamento da maneira como os bens são dispostos na sociedade capitalista. A narrativa também mostra como o poder econômico e as posições sociais privilegiadas são usadas como forma de opressão, humilhação e diminuição do ser humano. A história, pautada pelo exercício da crueldade de uma personagem em relação à outra, torna-se ainda mais cruel, uma vez que as personagens principais são duas crianças, 
que crescerão e, em tese, se manterão socialmente apartadas, numa representação de como se constrói e se estrutura o tecido social.

O problema da desigualdade social narrado em Felicidade clandestina (1971) cresceu e se proliferou com o passar do tempo, atingindo níveis absurdos, como nunca na história da humanidade. Sobre essa questão, Zygmunt Bauman, em A riquęa de poucos beneficia a todos? (2015) afirma que:

\begin{abstract}
A obstinada persistência da pobreza no planeta que vive os espasmos de um fundamentalismo do crescimento econômico é bastante para levar as pessoas atentas a fazer uma pausa e refletir sobre as perdas diretas, bem como sobre os efeitos colaterais da distribuição de riqueza. $\mathrm{O}$ abismo crescente que separa os pobres e os sem perspectiva de abastados, otimistas, autoconfiantes e exuberantes abismo cuja profundidade já excede a capacidade de todos [...]. (BAUMAN, 2015, p.10)
\end{abstract}

Assim, a atenção que Clarice Lispector dedica às questões sociais aponta para uma autora preocupada em marcar sua prosa com as tintas do seu tempo, mantendo-se atenta ao cotidiano que a cercava. Deste modo, compreendemos que Lispector detinha a consciência da vida cotidiana como algo comum a todos, observando e colhendo das situações mais banais do dia-a-dia a seiva necessária para a produção da sua literatura. Sobre o lugar do ser humano e sua relação com o cotidiano, convém observarmos o que afirma Agnes Heller em O cotidiano e a história (2015):

A vida cotidiana é a vida de todo homem. Todos a vivem, sem nenhuma exceção, qualquer que seja seu posto na divisão do trabalho intelectual e físico. Ninguém consegue identificar-se com sua atividade humano-genérica a ponto de poder desligar-se inteiramente da cotidianidade. E, ao contrário, não há nenhum homem, por mais "insubstancial" que seja, que viva tão somente na cotidianidade, embora essa o absorva preponderantemente. A vida cotidiana é a vida do homem inteiro; ou seja, o homem participa da vida cotidiana com todos os aspectos de sua individualidade, de sua personalidade. Nela, colocam-se "em funcionamento" todos os seus sentidos, todas as suas capacidades intelectuais, suas habilidades manipulativas, seus sentimentos, paixões, ideias, ideologias. (HELLER, 2016, p.35)

A presença de aspectos cotidianos, logo sociopolíticos, na literatura, em geral, e na literatura de Clarice Lispector, em específico, marcam o caráter social da literatura, como bem defende Antonio Candido. Para o autor de Literatura e sociedade (2000) houve um tempo em que fazer tal afirmação seria considerado grande absurdo. Hoje, no entanto, é impossível, sem se desconsiderar outros fatores, refutar a dimensão sociopolítica da arte como elemento indispensável ao submetê-la a uma interpretação estética. $\mathrm{O}$ avanço da teoria e da crítica contribuiu para se perceber que, na análise de uma obra literária, pela abertura propiciada pela própria obra, aportes de variados campos do conhecimento são oportunos. Sobre o resultado dos percursos teórico-críticos que se deram até chegarmos à compreensão de que 
os elementos sociais externos se transformam em elementos internos da obra literária, Antonio Candido diz:

\begin{abstract}
Hoje sabemos que a integridade da obra não permite adotar nenhuma dessas visões dissociadas; e que só a podemos entender fundindo texto e contexto numa interpretação dialeticamente íntegra, em que tanto o velho ponto de vista que explicava pelos fatores externos, quanto o outro, norteado pela convicção de que a estrutura é virtualmente independente, se combinam como momentos necessários do processo interpretativo. Sabemos, ainda, que o externo (no caso, o social) importa, não como causa, nem como significado, mas como elemento que desempenha um certo papel na constituição da estrutura, tornando-se, portanto, interno. (CANDIDO, 2000, p. 6)
\end{abstract}

Neste sentido, Clarice Lispector recorre a determinados elementos do cotidiano social, transformando-os em elementos internos de suas narrativas, como se dá, por exemplo, no conto "A bela e a fera ou a ferida grande demais", publicado no livro A Bela e a Fera, de 1999. O referido livro está organizado em duas partes. Na primeira parte, tem-se os contos inéditos escritos pela autora em 1940 e 1941, tendo sido incorporados a estes, na segunda parte, dois contos escritos no ano de 1977, somando oito contos ao todo.

Em "A bela e a fera ou a ferida grande demais" o foco da narrativa se dá, principalmente, na figura da personagem Carla, mulher branca, linda e rica, que não tem (ou finge não ter) nenhuma noção a respeito da sociedade brasileira. Ela era "como uma fotografia colorida fora de foco" (LISPECTOR, 1999a, p.99). Assim, a personagem é descrita como fútil, vazia e ignorante, sendo apresentada como um verdadeiro retrato da elite financeira brasileira. Diz a narradora: "Bem, então saiu do salão de beleza pelo elevador do Copacabana Palace Hotel. O chofer não estava lá” (LISPECTOR, 1999a, p. 95). É, no entanto, por meio do que Carla pensa e fala que a narrativa expõe as desigualdades sociais ao leitor.

Alheia ao contexto social que existia para além da sua cabeça cheia de festas e dos jantares que costumava dar para trinta, quarenta pessoas, Carla, cujo nome completo era Carla de Sousa e Santos, sofre um choque de realidade ao se deparar, enquanto espera seu chofer, com um mendigo que lhe pede uma esmola para comprar comida. A presença do mendigo sem uma das pernas atormenta Carla que, sem saber o que fazer, pensa o que seu marido banqueiro faria naquela situação. Então, num átimo, Carla passa a refletir não apenas sobre sua condição de mulher casada com um homem rico e influente, membro da alta burguesia carioca, mas sobre o seu estar-no-mundo, o que a leva a compreender seu vazio existencial.

Assim como nas outras narrativas mencionadas, em "A bela e a fera ou a ferida grande demais" nota-se a presença de aspectos dicotômicos já no título do conto: "bela e fera", que apontam para as desigualdades sociais da sociedade brasileira. Neste conto, tem-se, de um 
lado, um homem relegado socialmente ao mais baixo estágio da escala humana e, do ouro lado, a riqueza e a ostentação dos ricos e poderosos, representados pela figura fina e elegante de Carla. Embora trate-se de uma obra de ficção, as personagens desta narrativa guardam aproximações com seres de carne e osso comuns ao contexto sócio-histórico, político e cultural do Brasil do período histórico em que o conto foi escrito. A respeito da construção de personagens fictícios e sua aproximação com a realidade, Fabio Lucas (1970, p. 70) afirma:

Há [...] personagens, grupos e classes retratados na ficção, cuja vida, bem ou mal lograda, numa ordem épica ou trágica, se torna cabalmente representativa da situação histórica que a determina: os conflitos subjacentes à trama social aí aparecem nitidamente, quer sob um aspecto positivo, contribuidor, quer sob um aspecto negativo, de posição crítica e condenadora da ordem considerada injusta [...]. (LUCAS, 1970, p. 70)

O conto "A bela e a fera ou a ferida grande demais" é, sem sombra de dúvidas, uma das críticas sociais mais contundentes observáveis na narrativa clariciana, que se dá a partir da exposição de Carla ao mundo real. A consciência da existência de outra realidade faz com que a personagem seja tomada por uma revelação que desvela não apenas a si mesma, mas também o outro, o marginalizado e invisibilizado (o mendigo "não tem" nome), fazendo a personagem se desesperar: "Desesperou-se tanto que lhe veio o pensamento feito de duas palavras apenas: "Justiça Social” (LISPECTOR, 1999a, p.99).

Retomando o aspecto dicotômico do texto, infere-se que a relação bela/fera não se se refere à relação Carla/mendigo, mas sim a uma relação entre Carla/consciência social, sendo a consciência social a fera que, há tempos, ameaça devorar a personagem. O choque de realidade que acomete a personagem, assustou-a tanto, que a tirou da zona de conforto na qual se abrigara por muito tempo, pois:

[...] Sempre tivera medo das coisas belas demais ou horríveis demais: é que não sabia em si como responder-lhes e se responderia se fosse igualmente bela ou igualmente horrível. Estava assustada como quando vira o sorriso de Mona Lisa, ali, à sua mão no Louvre. Como se assustara com o homem da ferida ou com a ferida do homem. (LISPECTOR, 1999a, p.101)

A imagem do mendigo, em oposição a suntuosidade do Copacabana Palace, é mais um indicativo do abismo social que separa os seres humanos em classes, excluindo-se os menos favorecidos. Assim sendo, tem-se um homem (o mendigo) que tem uma ferida, e tem-se, ao mesmo tempo, a ferida do Homem, ou seja, uma ferida como metáfora das infelicidades, misérias e dores do mundo. Logo, uma ferida grande demais. 


\section{Considerações finais}

Clarice Lispector (1920-1977) se insere no cânone da arte brasileira, com uma literatura reconhecida, sem dúvidas, como atemporal e universal, tendo em vista estar em consonância com seu tempo histórico e ser de alta qualidade literária. Embora sua obra esteja cronologicamente situada, tendo começado na década de 40, com a publicação do romance Perto do coração selvagem (1943) e indo até o ano de 1977, com a publicação da novela $A$ bora da estrela, não se perdeu nos escaninhos da memória da literatura nacional. Ao contrário, a literatura de Clarice Lispector se expande a cada novo dia, propiciando novas possibilidades de estudo, não apenas em língua portuguesa, mas em vários outros idiomas.

A obra da autora de A paixão segundo G.H (1964) mostra-se como um manancial de possibilidades temáticas, que vão desde os temas mais intimistas até os mais abrangentes e questionadores. Assim sendo, Lispector demarca posição no contexto da literatura produzida no século XX, colocando-se no mesmo patamar qualitativo de autores referenciais do movimento Modernista europeu, como James Joyce, Virginia Woolf (1882-1941) e Samuel Beckett (1906-1989), por exemplo, cujas temáticas mais comuns em seus trabalhos estão, assim como em Lispector, em consonância com os acontecimentos que fizeram do século XX um século uma era bastante movimentada, cultural e politicamente.

Palco das principais manifestações culturais, o século XX também viu surgirem os priores conflitos bélicos da história da humanidade, a saber, a Primeira Guerra Mundial e a Segunda Guerra Mundial, surgidos no lastro dos regimes autoritários como o nazismo e o fascismo, o que acabou por militarizar as relações internacionais, isolando nações, minando as tradicionais formas diplomáticas e, consequentemente, enfraquecendo as democracias. Muitos países sucumbiram ao julgo de ditadores, muitos dos quais transformaram a América Latina no ambiente propício para o exercício do terror, por meio de perseguições, censuras, banimentos, torturas e mortes.

É neste contexto histórico que surge a maior parte da obra de Clarice Lispector, ou seja, sua literatura é praticamente toda ela gestada no período da ditadura civil-militar, que dominou o Brasil, instalando-se no poder por vinte e um anos, indo de 1964 até 1985. Uma vez que Clarice Lispector começa a publicar em 1943 e morre em 1977, sua obra é, então, produzida enquanto o país vivia esta situação. Sabendo-se, como afirma Antonio Candido (2000), que há uma relação dialética entre a obra de arte e o meio no qual ela é produzida, quando elementos sociais externos tornam-se elementos internos na construção do texto literário, defendemos no decorrer do presente artigo, que os aspectos sociopolíticos presentes na narrativa clariciana não são nem mais nem menos importantes que outros, mas são 
indispensáveis para a compreensão da construção do sentido do seu texto e de extrema relevância para a compreensão da sua obra, produzida no calor do coração selvagem do Brasil das décadas de 60 e 70 do século XX.

\title{
CLARICE LISPECTOR'S NARRATIVE IN THE WILD HEART OF BRASIL IN THE 20th CENTURY: SOME SOCIOPOLITICAL ASPECTS
}

\begin{abstract}
The aim of this paper consists on a brief analysis about Clarice Lispector's literature, mainly on her chronicles "Mineirinho" (1962) and "Carta ao Ministro da Educação" (1968), followed by her novella $A$ hora da estrela (1977) and also two of her most known short stories: "Felicidade clandestina" (1971) e "A bela e a fera ou a ferida grande demais" (1977). Once Clarice Lispector's literary work is vast and recognized for its diversity of themes, we focus this analysis on the social and political aspects observed on her literary narratives. So analyzing Clarice Lispector's literature focusing on its sociopolitical aspects is relevant once frequently these kind of aspectos are put aside in most of literary analysis written about her work. As a theoretical basis, we used Candido (2000), Lucas (1970), Hobsbawm (1995), Bauman (2015) e Heller (2016) among others.
\end{abstract}

KEYWORDS: Brazilian literature; Clarice Lispector; Narratives; Politics; Society.

\section{REFERÊNCIAS}

ARAÚJO, Paulo Cesar de. Eu não sou cachorro, não. Rio de Janeiro: Record, 2015.

BAUMAN, Zygmunt. A riqueza de poucos beneficia todos nós? Trad. Renato Aguiar. Rio de Janeiro: Zahar, 2015.

BORELLI, Olga. Clarice Lispector: esboço para um possível retrato. Rio de Janeiro: Nova Fronteira, 1981.

CANDIDO, Antonio. Literatura e sociedade. São Paulo: T. A. Queiroz, 2000.

CHIAPPINNI, Ligia. Clarice e a crítica: por uma perspectiva integradora. In: PONTIERI, Regina Lúcia. (Org.) Leitores e leituras de Clarice Lispector. São Paulo: Hedra, 2004, p.235-268.

HELLER, Agnes. O cotidiano e a história. Trad. Carlos Nelson Coutinho e Leandro Konder. São Paulo/Rio de Janeiro: Paz e Terra, 2016.

HOBSBAWM, Eric. Era dos Extremos: o breve século XX: 1914-1991. Trad. Marcos Santarrita. São Paulo: Companhia das Letras, 1995.

LISPECTOR, Clarice. A descoberta do mundo. Rio de Janeiro: Francisco Alves, 1992.

- Felicidade clandestina. Rio de Janeiro: Rocco, 1998.

- A bela e a fera. Rio de Janeiro: Rocco, 1999a.

. Para não esquecer. Rio de Janeiro: Rocco, 1999b.

. Carta ao ministro da Educação. In: Todas as crônicas. Rio de Janeiro: Editora Rocco, 2018, p. 77-78.

LUCAS, Fábio. O caráter social da literatura brasileira. Rio de Janeiro: Paz e Terra, 1970.

MOSER, Benjamim. Clarice, uma biografia. Trad. José Geraldo Couto. São Paulo: Cosac Naify, 2009. 